\title{
PENERAPAN SUPERVISI KOLABORATIF UNTUK MENINGKATKAN KOMPETENSI PROFESIONAL GURU DALAM MENGEMBANGKAN BAHAN AJAR
}

\author{
Jasmin \\ SMA Negeri 1 Bunyu, Kalimantan Utara, Indonesia \\ Email: jasminpasaka12@gmail.com
}

\begin{abstract}
The research objectives are to describe: 1) the development of a collaborative supervision process to improve teacher professional competence in developing teaching materials; 2) increasing the professional competence of teachers in SMA Negeri 1 Bunyu after applying the collaborative supervision approach. This research is a qualitative research, with aapproach phenomenological qualitative descriptive. Qualitative data were obtained from observation sheets and interviews. Meanwhile, the quantitative data were obtained from the test results. The test consists of two cycles. Data were analyzed using Kemmis and Mc. Taggart which is a development model of Kurt Lewin's model. It is said that, because in a cycle consists of four components, the four components include: (1) planning, (2) action / action, (3) observation, and (4) reflection. The benefits of this research can be used as a reference to serve as an alternative approach to supervision to improve teacher competence and school quality as a result of increasing the quality of teacher work in carrying out their professional duties.
\end{abstract}

Keywords: collaborative supervision; professional competence; learning activities

\begin{abstract}
Abstrak
Tujuan penelitian untuk mendeskripsikan: 1) perkembangan proses supervisi kolaboratif untuk meningkatkan kompetensi profesional guru dalam mengembangkan bahan ajar ; 2) peningkatan kompetensi profesional guru di SMA Negeri 1 Bunyu setelah diterapkan pendekatan supervisi kolaboratif. Penelitian ini merupakan penelitian kualitatif, dengan pendekatan deskriptif kualitatif fenomenologik. Data kualitatif diperoleh dari lembar observasi serta wawancara. Sedangkan data kuantitatif diperoleh dari hasil tes. Tes terdiri atas dua siklus. Data dianalisis menggunakan, model Kemmis dan Mc. Taggart yang merupakan model pengembangan dari model Kurt Lewin. Dikatakan demikian, karena di dalam suatu siklus terdiri atas empat komponen, keempat komponen tersebut, meliputi: (1) perencanaan, (2) aksi/ tindakan, (3) observasi, dan (4) refleksi. Manfaat dari Penelitian ini bisa menjadi rujukan untuk dijadikan sebagai alternatif pendekatan supervisi untuk meningkatkan kompetensi guru dan kualitas sekolah sebagai dampak meningkatnya kualitas kerja guru dalam melaksanakan tugas profesionalnya.
\end{abstract}

Kata Kunci: supervisi kolaboratif; kompetensi professional; kegiatan pembelajaran

\begin{tabular}{ll}
\hline How to cite: & Jasmin (2021) Penerapan Supervisi Kolaboratif untuk Meningkatkan Kompetensi Profesional Guru \\
& dalam Mengembangkan Bahan Ajar. Syntax Idea 3(4). http://dx.doi.org/10.36418/syntax-idea.1145 \\
E-ISSN: & 2684-883X \\
Published by: & Ridwan Institute
\end{tabular}




\section{Pendahuluan}

Guru merupakan sosok yang begitu dihormati karena memiliki sumbangan yang cukup besar terhadap keberhasilan pembelajaran di sekolah. Guru sangat berperan dalam membantu perkembangan peserta didik untuk mencapai kemampuan optimalnya. Ketika orang tua mendaftarkan anaknya di setiap jenjang pendidikan pada sekolah tertentu, pada saat itu juga ia menaruh harapan cukup besar terhadap guru, agar anaknya dapat memperoleh pendidikan, pembinaan dan pembelajaran serta bimbingan sehingga anak tersebut dapat berkembang secara optimal (Hamid, 2017).

Guru merupakan ujung tombak keberhasilan pendidikan. Profesionalisme seorang guru terlihat dari kompetensinya sebagai seorang guru yang terdiri dari kompetensi pedagogik, profesional, keperibadian dan sosial (Mulyani, 2019). Salah satu dimensi kompetensi guru sesuai dengan (Peraturan Menteri Pendidikan Nasional Republik Indonesia Nomor 16 Tahun, 2007) tentang Standar Kualifikasi Akademik dan Kompetensi Guru adalah kompetensi profesional. Dengan Permendiknas tersebut berarti seorang guru harus kompeten dalam melakukan kinerja profesionalnya. Kompetensi profesional guru menurut (Permendiknas Nomor 16, 2007) terdiri dari kemampuan guru dalam: (1) menguasai materi, struktur, konsep, dan pola pikir keilmuan yang mendukung mata pelajaran yang diampu; (2) menguasai standar kompetensi dan kompetensi dasar mata pelajaran/ bidang pengembangan yang diampu; (3) mengembangkan materi pembelajaran yang diampu secara kreatif; (4) mengembangkan keprofesionalan secara berkelanjutan dengan melakukan tindakan reflektif; dan (5) memanfaatkan teknologi informasi dan komunikasi untuk berkomunikasi dan mengembangkan diri.

Guru merupakan salah satu faktor penentu tinggi rendahnya mutu hasil pendidikan mempunyai posisi strategis maka setiap usaha peningkatan mutu pendidikan perlu memberikan perhatian besar kepada peningkatan guru baik dalam segi jumiah maupun mutunya. Pengembangan profesional guru harus diakui sebagai suatu ha! yang sangat fundamental dan penting guna meningkatkan mutu pendidikan. Perkembangan profesional adalah proses dimana guru dan kepala sekolah belajar meningkatkan dan menggunakan pengetahuan, ketrampilan dan nilai secara tepat. Guru mempunyai peranan yang sangat penting untuk menjadikan anak didik memiliki akhlak mulia dan mampu menjaga kedamaian dan kerukunan (Anwar, 2011).

Pendidikan sebagai sebuah kegiatan dan proses aktivitas yang disengaja merupakan gejala masyarakat ketika sudah mulai disadari pentingnya upaya untuk membentuk, mengarahkan, dan mengatur manusia sebagaimana dicita-citakan masyarakat (Heri, 2012).

Inti dari pendidikan adalah proses belajar mengajar. Semakin baik proses belajar mengajar yang dilaksananakan maka akan semakin baik pula mutu pendidikan. Untuk memperbaiki kualitas proses belajar mengajar, ada tiga elemen yang perlu diperhatikan, yaitu guru, peserta didik dan kurikulum atau materi pembelajaran (Dudung, 2018).

Strategi belajar mengajar penting untuk direncanakan dan dilaksanakan guru. Seorang guru selayaknya sama dengan seorang panglima perang, setiap panglima 
perang pasti mahir strategi berperang. Semua strategi yang ia gunakan dilakukan dalam rangka memenangkan peperangan (Barlian, 2013).

Efektivitas pelaksanaaan kinerja profesional guru sangat bergantung pada kompetensi kepala sekolah dalam melaksanakan tugasnya diantaranya dalam melakukan supervisi akademik (Sitaasih, 2020). Untuk melaksanakan supervisi akademik, kepala sekolah sebagai supervisor dan penanggungjawab kegiatan di sekolah harus mampu menyusun program, melaksanakan, dan melakukan tindak lanjut supervisi akademik di sekolah yang dipimpinnya (Simbolon, 2018).

Pelaksanaan supervisi akademik yang baik oleh kepala sekolah akan menghasilkan kompetensi guru dalam memfasilitasi pembelajaran yang baik pula. Selanjutnya, pembelajaran yang dilaksanakan dengan baik akan berdampak pada peningkatan prestasi siswa. Dengan demikian, keberhasilan siswa dalam pembelajaran sangat bergantung pada kemampuan guru dalam memfasilitasi pembelajaran dan kompetensi kepala sekolah dalam melaksanakan supervisi akademik (Sabandi, 2013).

Supervisi akademik yang diterapkan kepala sekolah tentunya sangat efektif, karena dapat memberikan bantuan, bimbingan dan pembinaan kepada guru agar mereka mampu bekerja lebih baik dalam membimbing peserta didik serta dapat memperbaiki kinerjanya dalam meningkatkan pembelajaran di sekolah (Ajasan, 2016).

Kompetensi supervisi akademik kepala sekolah terdiri dari tiga aspek yaitu kompetensi dalam menyusun program, melaksanakan, mengevaluasi dan menindaklanjuti temuan-temuan ketika melaksanakan supervisi akademiknya (Prayoga, 2020). Program supervisi akademik yang harus disusun oleh seorang kepala sekolah merupakan pedoman atau acuan dalam melaksanakan supervisi akademik. Selain itu, program supervisi akademik juga dapat mengembangkan kemampuan guru dalam mengelola pembelajaran secara efektif. Dari hasil pelaksanaan supervisi akademik, kepala sekolah juga harus mampu merefleksi kinerjanya dan melaksanakan tindak lanjut sebagai umpan balik yang sangat berguna untuk peningkatan kualitas baik bagi siswa, guru, maupun dirinya yang pada akhirnya dapat meningkatkan kualitas pendidikan di sekolahnya (Kodariah, Herawan, \& Sutarsih, 2016).

Berdasarkan hasil refleksi diri yang telah dilakukan oleh peneliti sebagai kepala sekolah, selama ini kepala sekolah melaksanakan tugas supervisi akademiknya dengan menerapkan pendekatan supervisi langsung secara individual, dengan cara mendatangi guru yang sedang bertugas, mengamati kinerjanya dan melakukan penilaian. Pendekatan supervisi individual ini tidak terlalu efektif untuk meningkatkan kompetensi guru dalam melaksanakan tugasnya khususnya yang berkaitan dengan kompetensi profesionalnya. Hasil kajian empirik yang peneliti lakukan terhadap guru-guru di SMA Negeri 1 Bunyu menunjukkan bahwa kompetensi profesional guru masih rendah terutama pada kompetensi guru dalam mengembangkan materi pembelajaran yang diampu secara kreatif. Rata-rata kemampuan guru dalam mengembangkan materi pembelajaran yang diampunya berdasarkan penilaian kinerja guru terhadap 11 orang guru di SMA Negeri 1 Bunyu, diperoleh data sebagai berikut 
Tabel 1

Kemampuan guru dalam mengembangkan bahan ajar yang diampu secara kreatif

\begin{tabular}{|c|c|c|c|}
\hline \multirow{2}{*}{ No. } & \multirow{2}{*}{ Aspek } & \multicolumn{2}{|c|}{ Rata-rata } \\
\hline & & Skala 4 & Skala 100 \\
\hline 1. & Keterurutan & 2,14 & 53,41 \\
\hline 2. & Keberjenjangan & 2,27 & 56,82 \\
\hline 3. & Kedalaman & 1,77 & 44,32 \\
\hline 4. & Keluasan & 2,18 & 54,55 \\
\hline Nila & Rata-rata Keseluruhan & 2,09 & 52,27 \\
\hline
\end{tabular}

Hasil analisis data pada tabel di atas menunjukkan bahwa kompetensi guru dalam mengembangkan materi pembelajaran yang diampu masih pada kategori kurang yaitu indeks rata-rata 2,09 atau 52,27. Hasil refleksi terhadap temuan tersebut menunjukkan bahwa faktor yang menyebabkan masih rendahnya kompetensi guru tersebut diduga disebabkan oleh faktor internal dan eksternal. Faktor internal yang diduga mempengaruhi rendahya kompetensi profesional guru antara lain:

1. Guru belum memahami teknik pengembangan materi pembelajaran;

2. Guru tidak melakukan analisis materi pembelajaran sebelum mengembangkan bahan ajar atau materi pembelajaran; dan

3. Kurangnya motivasi diri guru untuk melakukan kinerja profesionalnya dengan baik.

Faktor eksternal yang diduga mengakibatkan rendahnya kompetensi profesional guru adalah pelaksanaan supervisi oleh kepala sekolah yang lebih bersifat menilai. Idealnya, supervisi dilaksanakan secara kolegial, tidak menggurui, bersifat kemitraan dan pendampingan, serta dilakukan melalui diskusi dan curah pendapat secara terbuka dan fleksibel untuk membantu guru merefleksi kinerjanya dalam melaksanakan tugas profesionalnya. Salah satu pendekatan yang mengedepankan kemitraan atau rekan kerja antara kepala sekolah sebagai supervisor akademik dan guru sebagai orang yang disupervisi, lebih bersifat mendampingi melalui diskusi dan curah pendapat secara terbuka dan fleksibel serta memiliki tujuan yang jelas untuk membantu guru berkembang menjadi tenaga-tenaga profesional melalui kegiatan-kegiatan reflektif adalah pendekatan supervisi kolaboratif (Simbolon, 2018). Oleh karenanya, pada penelitian ini peneliti mencoba untuk mengatasi masalah rendahnya kompetensi profesional guru dalam melaksanakan tugas profesionalnya, dengan menerapkan tindakan berupa pendekatan supervisi yang belum pernah dilakukan sebelumnya yaitu pendekatan supervisi kolaboratif. Tindakan tersebut selanjutnya diteliti melalui penelitian tindakan sekolah yang berjudul "Penerapan Supervisi Kolaboratif untuk Meningkatkan Kompetensi Profesional Guru dalam Mengembangangkan Bahan Ajar" di SMA Negeri 1 Bunyu Tahun Pelajaran 2020/2021. 


\section{Metode Penelitian}

Penelitian ini bertujuan untuk mendeskripsikan pelaksanaan supervisi kolaboratif guru di SMA Negeri 1 Bunyu. Pendekatan yang diterapkan adalah pendekatan supervisi kolaboratif menggunakan metode Penelitian Tindakan Sekolah (PTS) dengan model Kemmis dan Mc. Taggart yang merupakan model pengembangan dari model Kurt Lewin (Sampirni, 2020). Dikatakan demikian, karena di dalam suatu siklus terdiri atas empat komponen, keempat komponen tersebut, meliputi: (1) perencanaan, (2) aksi/ tindakan, (3) observasi, dan (4) refleksi. Setelah satu siklus selesai diimplementasikan, khususnya sesudah adanya refleksi, kemudian diikuti dengan adanya perencanaan ulang yang dilaksanakan dalam bentuk siklus kedua. Teknik pengolahan dan analisis data dilakukan secara kuantitatif dan kualitatif. Teknik pengolahan data secara kuantitatif dilakukan terhadap variabel kompetensi profesional guru. Data yang diperoleh dari hasil pengamatan atau observasi kinerja profesional guru dalam mengembangkan bahan ajar yang terdiri dari empat aspek yaitu keterurutan, keberjenjangan, kedalaman, dan keluasan materi.

\section{Hasil dan Pembahasan}

\section{A. Proses supervisi kolaboratif dan kompetensi profesional guru pada siklus I}

Pendekatan supervisi kolaboratif pada Siklus I dilaksanakan dengan menerapkan lima prinsip pendekatan supervisi kolaboratif yaitu prinsip kolaboratif, kolegial, kemitraan, terbuka dan fleksibel melalui tahapan-tahapan spesifik sebagai berikut:

1. Tahap pra-supervisi kolaboratif, kepala sekolah bersama 11 guru melaksanakan curah pendapat dan diskusi di sekolah difasilitasi oleh kepala sekolah tentang masalah-masalah krusial guru dalam mengembangkan materi pembelajaran dan bahan ajar.

2. Tahap supervisi kolaboratif, kepala sekolah melaksanakan supervisi kolaboratif bersama guru pada saat guru sedang melaksanakan kinerja profesionalnya dengan menerapkan kelima prinsip pendekatan supervisi kolaboratif yaitu prinsip kolaboratif, kolegial, kemitraan, terbuka dan fleksibel.

3. Tahap pasca-supervisi kolaboratif, kepala sekolah bersama 11 guru melaksanakan refleksi pelaksanaan kinerja profesionalnya difasilitasi oleh kepala sekolah.

Temuan-temuan selama proses supervisi kolaboratif berlangsung dikumpulkan menggunakan lembar observasi proses supervisi kolaboratif dan catatan lapangan. Peneliti sebagai observer mengamati keterlaksanaan supervisi dengan menerapkan pendekatan supervisi kolaboratif yang selanjutnya memberikan deskripsi pada kolom yang telah disediakan pada lembar observasi proses supervisi kolaboratif. 
Tabel 2

Deskripsi hasil observasi proses supervisi dengan menerapkan pendekatan supervisi kolaboratif pada siklus i

\begin{tabular}{cll}
\hline No & Tahapan Spesifik & \multicolumn{1}{c}{ Temuan } \\
\hline 1 & Tahap Pra-Supervisi & $\begin{array}{l}\text { Seluruh guru tidak membawa daftar masalah terkait } \\
\text { kompetensi profesionalnya dalam mengembangkan } \\
\text { Kateri pembelajaran dan bahan ajar, curah pendapat } \\
\text { dan diskusi tidak berjalan dengan baik, hanya satu } \\
\text { orang guru yang aktif mencurahkan pendapatnya }\end{array}$ \\
\hline 2 & Tahap Pelaksanaan & $\begin{array}{l}\text { Dua guru tidak menyiapkan perangkat dan materi } \\
\text { pembelajaran sehingga mengganggu proses supervisi } \\
\text { kolaboratif }\end{array}$ \\
\hline 3 & Tahapervisi Kolaboratif Pasca- & $\begin{array}{l}\text { Seluruh guru terlibat dalam proses refleksi } \\
\text { pelaksanaan supervisi kolaboratif dengan } \\
\text { menyampaikan temuan dan pemecahannya }\end{array}$ \\
\hline
\end{tabular}

Kompetensi profesional guru ini terdiri dari kemampuannya dalam mengembangkan bahan ajar. Kompetensi guru dalam melaksanakan kinerja profesionalnya diamati dan diukur menggunakan lembar observasi kinerja professional guru dalam mengembangkan bahan ajar. Berikut merupakan rata-rata kompetensi profesional guru di SMA Negeri 1 Bunyu yang diukur dan diamati terhadap 11 guru.

Tabel 3

Hasil validasi pengembangan bahan ajar guru oleh ahli

\begin{tabular}{llcl}
\hline No & Aspek yang dinilai & $\begin{array}{c}\text { Rata-rata hasil } \\
\text { penilaian }(\boldsymbol{\%})\end{array}$ & Kriterian \\
\hline 1 & Keterurutan & 90,00 & Sangat Baik \\
\hline 2 & Keberjenjangan & 85,40 & Baik \\
\hline 3 & Kedalaman & 55,80 & Kurang \\
\hline 4 & Keluasan materi & 50,60 & Kurang \\
\hline Rata -rata & 70,45 & Cukup \\
\hline
\end{tabular}

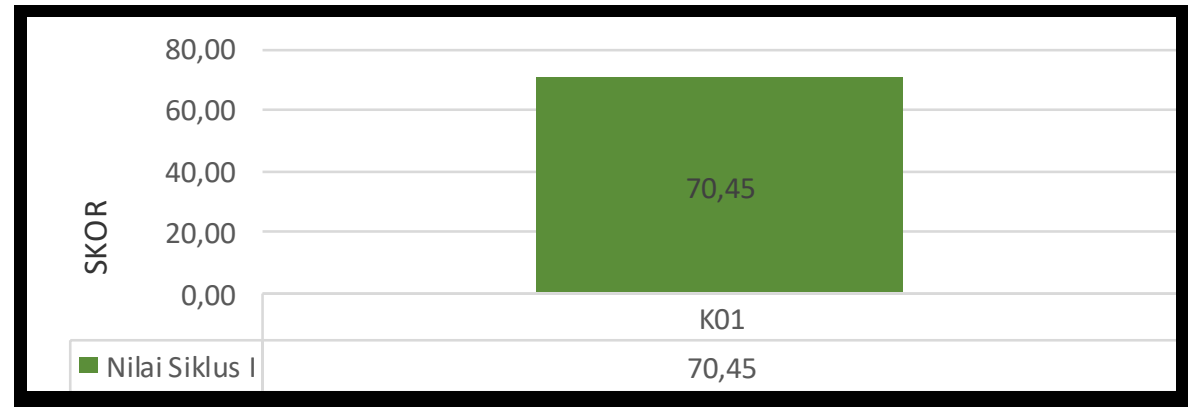

Grafik 1

Rata-rata kompetensi profesional guru dalam mengembangkan bahan ajar pada siklus i 
Analisis deskriptif terhadap kompetensi professional guru dalam mengembangkan bahan ajar pada siklus I memperoleh nilai 70,45 dengan kategori cukup. Sehingga peneliti melanjutkan penelitian ini pada siklus II.

\section{B. Proses Supervisi Kolaboratif dan kompetensi profesional guru pada Siklus II}

Supervisi kolaboratif pada Siklus II ini dilaksanakan berdasarkan rekomendasirekomendasi pada Siklus I dengan menerapkan kelima prinsip pendekatan supervisi kolaboratif yaitu prinsip kolaboratif, kolegial, kemitraan, terbuka dan fleksibel melalui tahapan-tahapan spesifik sebagai berikut:

1. Tahap pra-supervisi kolaboratif, kepala sekolah terlebih dahulu melakukan koordinasi dengan semua guru dan menjelaskan teknis supervisi kolaboratif yang akan dilaksanakan diantaranya mengindentifikasi masalah-masalah krusial ketika melaksanakan kinerja profesionalnya dalam mengembangkan materi pembelajaran dan bahan ajar, mencatat dan membawanya pada saat curah pendapat dan diskusi bersama kepala sekolah dan guru lainnya. Selanjutnya, kepala sekolah bersama 11 guru melaksanakan curah pendapat dan diskusi difasilitasi oleh kepala sekolah tentang masalah-masalah krusial yang teridentifikasi oleh guru dalam melaksanakan kinerja profesionalnya. Pada akhir tahap pra-supervisi kolaboratif, kepala sekolah menguatkan dan menegaskan kepada guru untuk menyiapkan kelengkapan diantaranya hasil analisis materi pembelajaran.

2. Tahap supervisi kolaboratif, kepala sekolah melaksanakan supervisi kolaboratif bersama guru pada saat guru lain sedang melaksanakan kinerja profesionalnya dengan menerapkan kelima prinsip pendekatan supervisi kolaboratif yaitu prinsip kolaboratif, kolegial, kemitraan, terbuka dan fleksibel.

3. Tahap pasca-supervisi, kepala sekolah bersama 11 guru melaksanakan refleksi pelaksanaan kinerja profesional dan supervisi kolaboratif difasilitasi oleh kepala sekolah.

Temuan-temuan selama proses supervisi kolaboratif berlangsung dikumpulkan menggunakan lembar observasi proses supervisi kolaboratif dan catatan lapangan. Peneliti sebagai observer mengamati keterlaksanaan supervisi dengan menerapkan pendekatan supervisi kolaboratif yang selanjutnya memberikan deskripsi pada kolom yang telah disediakan pada lembar observasi proses supervisi kolaboratif.

\section{Tabel 4}

Deskripsi hasil observasi proses supervisi dengan menerapkan pendekatan supervisi kolaboratif pada siklus ii

\begin{tabular}{cll} 
No & Tahapan Spesifik & \multicolumn{2}{c}{ Temuan } \\
\hline 1 & $\begin{array}{l}\text { Tahap Pra-Supervisi } \\
\text { Kolaboratif }\end{array}$ & $\begin{array}{l}\text { Curah pendapat dan diskusi berjalan dengan baik, } \\
\text { seluruh guru aktif berdiskusi dan mencurahkan } \\
\text { pendapatnya }\end{array}$ \\
\hline 2 & $\begin{array}{l}\text { Tahap Pelaksanaan } \\
\text { Supervisi Kolaboratif }\end{array}$ & $\begin{array}{l}\text { Pelaksanaan supervisi kolaboratif berjalan dengan } \\
\text { efektif, guru mampu menerapkan solusi-solusi dari }\end{array}$ \\
\hline
\end{tabular}




\begin{tabular}{lll}
\hline No & Tahapan Spesifik & \multicolumn{1}{c}{ Temuan } \\
\hline & & $\begin{array}{l}\text { masalah yang teridentifikasi sebelumnya sebagai } \\
\text { hasil curah pendapat dan diskusi dengan guru lain } \\
\text { dan kepala sekolah pada tahap pra-supervisi } \\
\text { kolaboratif. }\end{array}$ \\
\hline 3 & $\begin{array}{l}\text { Tahap Pasca-Supervisi } \\
\text { Kolaboratif }\end{array}$ & Seluruh guru terlibat dalam proses refleksi \\
\hline
\end{tabular}

Kompetensi profesional guru ini terdiri dari kemampuannya dalam mengembangkan materi pembelajaran dan bahan ajar. Kompetensi guru dalam melaksanakan kinerja profesionalnya diamati dan diukur menggunakan lembar observasi kinerja profesional guru dalam mengembangkan materi pembelajaran dan bahan ajar. Berikut merupakan rata-rata kompetensi profesional guru di SMA Negeri 1 Bunyu yang diukur dan diamati terhadap 11 guru.

Tabel 5

Hasil validasi pengembangan bahan ajar guru oleh ahli

\begin{tabular}{llcl}
\hline No & Aspek yang dinilai & $\begin{array}{c}\text { Rata-rata } \\
\text { hasil penilaian }(\%)\end{array}$ & Kriterian \\
\hline 1 & Keterurutan & 95,70 & Sangat Baik \\
\hline 2 & Keberjenjangan & 87,09 & Baik \\
\hline 3 & Kedalaman, & 86,70 & Baik \\
\hline 4 & Keluasan materi. & 85,06 & Baik \\
\hline Rata-rata & 88,64 & Baik \\
\hline
\end{tabular}

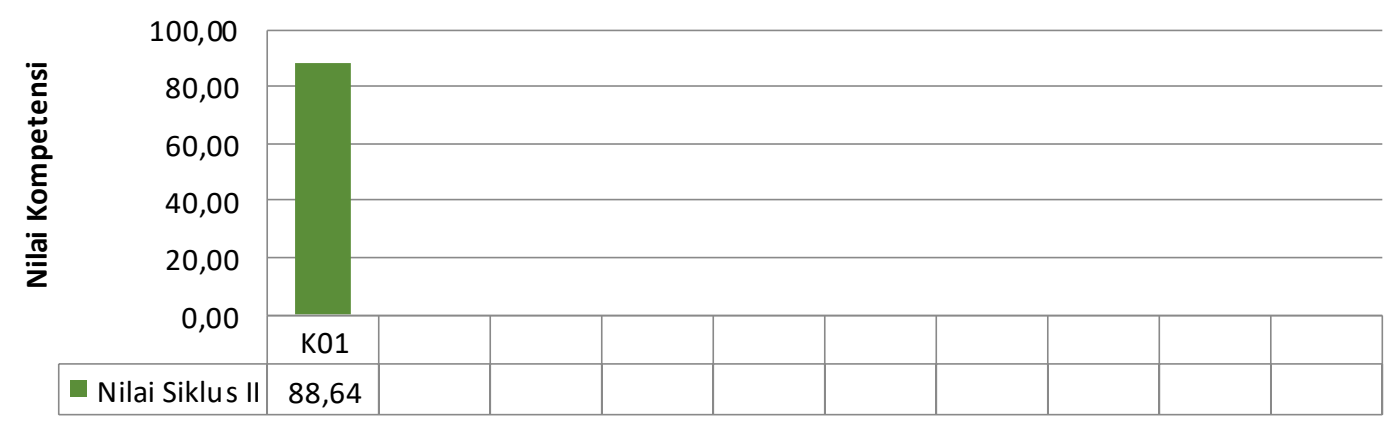

Dari hasil analisis deskriptif terhadap kompetensi professional guru dalam mengembangkan bahan ajar pada siklus II memperoleh nilai 88,64 dengan kategori baik. Sehingga pada pelaksanaan tindakan pada siklus II ini dikategorikan telah mencapai target dan ketuntasan belajar.

\section{Hasil Supervisi Kolaboratif dan kompetensi profesional Guru Setiap Siklus}

Dari Hasil Analisis deskriptif terhadap kompetensi professional guru dalam mengembangkan bahan ajar pada setiap siklus menunjukkan bahwa penerapan 
supervisi kolaboratif ini mampu meningkatkan kemampuan professional guru dalam mengembangkan bahan ajar.

\section{Tabel 6}

Peningkatan Kompetensi Profesional Guru

\begin{tabular}{cccc}
\hline Kompetensi & Pra-siklus & Siklus I & Siklus II \\
\hline Rata-rata & 52,27 & 70,45 & 88,64 \\
\hline Kriteria & Kurang & Cukup & Baik \\
\hline
\end{tabular}

Grafik 3. Peningkatan Kompetensi Profesional

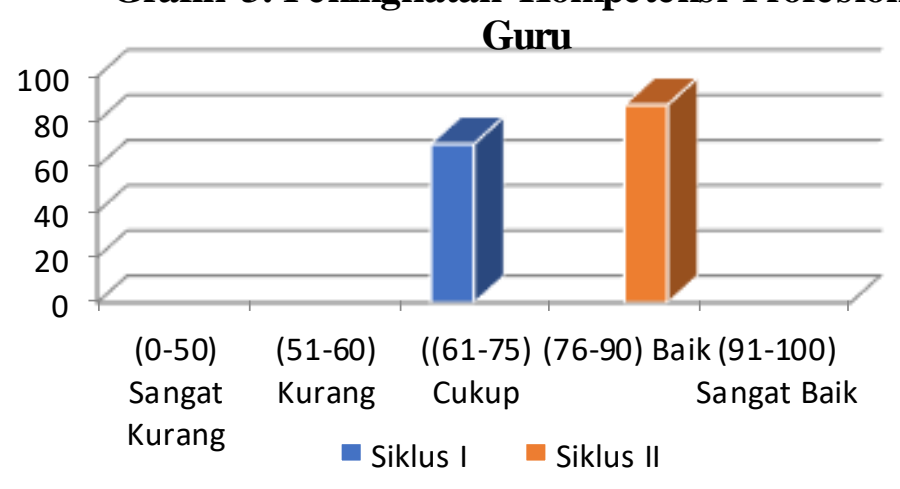

Tabel 6 dan Grafik 3 di atas menunjukkan bahwa kompetensi profesional guru mengalami peningkatan dari pra-siklus ke siklus I dan dari siklus I ke siklus II. Hal ini diduga bahwa pendekatan supervisi kolaboratif telah dilaksanakan secara efektif selamat proses supervisi baik pada tahap pra pelaksanaan, dan pasca-supervisi kolaboratif.

\section{Kesimpulan}

Berdasarkan pembahasan dalam penelitian mengenai penerapan pendekatan supervisi kolaboratif untuk meningkatkan kompetensi profesional guru dalam mengembangkan bahan ajar di SMA Negeri 1 Bunyu dapat disimpulkan, (1.) Proses supervisi dengan menerapkan pendekatan supervisi kolaboratif secara spesifik terdiri dari tahap pra-supervisi kolaboratif, supervisi kolaboratif dan pasca-supervisi kolaboratif. (2.) Proses supervisi dengan menerapkan pendekatan supervisi kolaboratif mengalami perkembangan dari siklus I ke siklus II. (3.) Pada tahap pra-supervisi kolaboratif ke siklus I, curah pendapat tidak berjalan dengan efektif karena kepala sekolah tidak melakukan koordinasi dengan semua guru dan tidak menjelaskan teknis supervisi kolaboratif yang akan dilaksanakan diantaranya mengindentifikasi masalahmasalah krusial ketika guru melaksanakan kinerja profesionalnya, sehingga guru tidak mencatat dan membawanya pada saat curah pendapat dan diskusi bersama kepala sekolah dan guru lainnya. (4.) Pada siklus II, kepala sekolah melakukan koordinasi dengan semua guru dan menjelaskan teknis supervisi kolaboratif yang akan dilaksanakan serta menguatkan dan menegaskan kepada guru untuk menyiapkan kelengkapan kinerja profesionalnya sehingga curah pendapat dan diskusi berjalan dengan tertib dan efektif. (5.) Pada tahap supervisi kolaboratif siklus I, proses supervisi 
kolaboratif terhambat karena ada guru yang tidak membawa kelengkapan terkait kinerja profesionalnya, sedangkan pada siklus II mereka membawa semua kelengkapan sehingga pelaksanaan supervisi kolaboratif berjalan dengan tertib. (6.) Pada tahap pasca-supervisi kolaboratif, kepala sekolah tidak koordinatif dengan semua guru dan tidak berhasil memotivasi guru untuk saling belajar. Sedangkan pada siklus II, kepala sekolah mulai koordinatif dengan semua dan berhasil memotivasi guru untuk saling belajar. (7.) Peningkatan kompetensi profesional guru di SMA Negeri 1 Bunyu dari pra-siklus ke siklus I sebesar 18,18 poin. Rata-rata kompetensi profesional guru pada pra-siklus sebesar 52,27 dengan kriteria kurang dan pada siklus I sebesar 70,45 dengan kriteria cukup. Kompetensi profesional guru juga mengalami peningkatan dari siklus I ke siklus II sebesar 18,19 poin. Rata-rata kompetensi profesional guru pada siklus II sebesar 88,64 dengan kriteria baik. Jadi, dapat disimpulkan bahwa kompetensi profesional guru di SMA Negeri 1 Bunyu dapat ditingkatkan melalui penerapan pendekatan supervisi kolaboratif. 
Penerapan Supervisi Kolaboratif untuk Meningkatkan Kompetensi Profesional Guru

\section{BIBLIOGRAFI}

Ajasan, Nasir Usman. (2016). Efektivitas pelaksanaan supervisi akademik oleh kepala sekolah dalam meningkatkan kinerja guru di Smk Negeri 1 Meulaboh. Jurnal Administrasi Pendidikan: Program Pascasarjana Unsyiah, 4(3).

Anwar, Rosihan. (2011). Pengaruh musyawarah guru mata pelajaran (MGMP) terhadap peningkatan profesionalisme dan kinerja mengajar guru sma negeri kota tasikmalaya. Jurnal Administrasi Pendidikan, 13(1). Google Scholar

Barlian, Ikbal. (2013). Begitu Pentingkah Strategi Belajar Mengajar Bagi Guru? Forum Sosial, 6(01), 241-246. Jurusan Pendidikan Ilmu Pengetahuan Sosial Fakultas Keguruan Dan Ilmu Google Scholar

Dudung, Agus. (2018). Kompetensi profesional guru. JKKP (Jurnal Kesejahteraan Keluarga Dan Pendidikan), 5(1), 9-19. Google Scholar

Hamid, Abdul. (2017). Guru Profesional. Al-Falah: Jurnal Ilmiah Keislaman Dan Kemasyarakatan, 17(2), 274-285. Google Scholar

Heri, Gunawan. (2012). Pendidikan karakter konsep dan implementasi. Bandung: Alfabeta, 7-31. Google Scholar

Kodariah, Wiwin, Herawan, Endang, \& Sutarsih, Cicih. (2016). Supervisi Akademik Kepala Sekolah, Motivasi Berprestasi Guru Dan Kinerja Mengajar Guru. Jurnal Administrasi Pendidikan, 23(2). Google Scholar

Mulyani, Nani. (2019). Pengembangan profesionalisme guru pada mtsn 1 serang melalui peningkatan kompetensi profesional dan pedagogik. Tarbawi: Jurnal Keilmuan Manajemen Pendidikan, 5(01), 87-96. Google Scholar

Peraturan Menteri Pendidikan Nasional Republik Indonesia Nomor 16 Tahun. (2007). Standar Kualifikasi Akademik dan Kompetensi Guru.

Permendiknas Nomor 16. (2007).

Prayoga, Ari. (2020). Supervisi Akademik Kepala Madrasah. INOVATIF: Jurnal Penelitian Pendidikan, Agama Dan Kebudayaan, 6(1), 105-124. Google Scholar

Sabandi, Ahmad. (2013). Supervisi pendidikan untuk pengembangan profesionalitas guru berkelanjutan. Pedagogi: Jurnal Ilmu Pendidikan, 13(2), 1-9. Google Scholar

Sampirni, Sampirni. (2020). Penerapan Pendekatan Supervisi Kolaboratif Untuk Meningkatkan Kompetensi Profesional Guru Di SD Negeri 9 Namang Kabupaten Bangka Tengah. Social Pedagogy: Journal of Social Science Education, 1(2), 162173. Google Scholar

Simbolon, Marike. (2018). Penerapan Pendekatan Supervisi Kolaboratif Untuk 
Jasmin

Meningkatkan Kompetensi Profesional Guru di SD Negeri 10 Lumban Suhisuhi Kecamatan Pangururan Kabupaten Samosir. Informasi Dan Teknologi Ilmiah (INTI), 6(1), 108-113. Google Scholar

Sitaasih, Desak Ketut. (2020). Supervisi Akademik untuk Meningkatkan Kompetensi

Guru Dalam Proses Pembelajaran di SD. Jurnal Ilmiah Sekolah Dasar, 4(2), 241247. Google Scholar

Copyright holder :

Jasmin (2021)

First publication right :

Journal Syntax Idea

This article is licensed under:

(cc) $(9) \Theta$ 